\title{
Prevalence of Cytomegalovirus Infection in Patients With Colorectal Cancer by Using PCR Technique
}

\author{
Sahar Mehrabani-Khasraghi, ${ }^{1,}{ }^{*}$ Masood Ghane, ${ }^{1}$ and Mitra Ameli ${ }^{2}$ \\ ${ }^{1}$ Department of Microbiology, Tonekabon Branch, Islamic Azad University, Tonekabon, IR Iran \\ ${ }^{2}$ Department of Medicine, Tonekabon Branch, Islamic Azad University, Tonekabon, IR Iran \\ "Corresponding author: Sahar Mehrabani-Khasraghi, Department of Microbiology, Tonekabon Branch, Islamic Azad University, Tonekabon, IR Iran. E-mail: \\ saharmehrabani1@gmail.com
}

Received 2015 January 30; Accepted 2015 August 02

\begin{abstract}
Background: Colorectal cancer is the most common gastrointestinal cancer and the second leading cause of cancer deaths worldwide.

Objectives: The purpose of this study is to investigate the prevalence of cytomegalovirus in patients with colorectal carcinomas and polyps in comparison with healthy people.

Patients and Methods: In this analytical case-control study, 15 patients with colorectal cancer, 20 patients with colorectal polyps and also 35 patients without malignancy as controls were studied. Biopsy specimens were frozen under sterile conditions at $-20^{\circ} \mathrm{C}$. After DNA extraction, analysis of polymerase chain reaction (PCR) to detect CMV DNA in tissue samples was performed. Statistical analysis was performed with $\chi^{2}$ test.

Results: CMV DNA were found in 8 (53.3\%) of tumor samples, in 10 (50\%) of polyp samples and 13 (37.1\%) of the non-malignant control group. Statistical analysis showed no significant association between the prevalence of CMV and incidence colorectal cancer and polyps in comparison with the control group.

Conclusions: The results of the present study has shown the presence of CMV sequences in differentiated cancer tissue, polyp and non-malignant by PCR method reflects the ability of the virus to infect of the different colon cells.
\end{abstract}

Keywords: Colorectal Cancer, Polyp, Cytomegalovirus, Polymerase Chain Reaction

\section{Background}

Colorectal cancer is the most common gastrointestinal cancer and the leading of cancer deaths in the United States of America [1]. Regarding the gender factor of colorectal cancer among women, after lung and breast cancer and in men after lung and prostate is the third rank of incidence. According to the world health organization, each year 875,000 new cases of the disease are recorded [2]. The incidence of colorectal cancer varies around the world, in America, western Europe, Australia and Japan has the largest rate and in African and Asian countries has the lowest rate [3]. The majority of colorectal cancers (regardless of the etiology) of adenoma polyps originate. Adenomatous polyps may be pedunculated or sessile; cancer is more common in sessile types. Adenomatous polyps could be tubular histology, villus and tubular-villus. Although many risk factors for development of the disease have been identified, such as the viral infection, the inherited genetic predisposition, the molecular mechanisms related to the colorectal carcinogenesis remain under investigation [4, 5]. Viral etiology of human malignancies is an intrigu- ing subject, with the exception of HCV, all the known human tumor viruses contain DNA as their genetic material [6]. The role of viral agents recognized in human tumors, such as cervical cancer by HSV, cancer of nose, throat and Burkitt's lymphoma by EBV, blood vessels cancer by HHV8, leukemia by HTLV, liver cancer by HCV and HBV, cervical and skin cancer by HPV and Hodgkin's disease by CMV.CMV is a member of the herpes virus family that is a ubiquitous worldwide. In the United States $40 \%$ - 90\% of adults are seropositive owing to exposure to the virus at some time during life [7]. CMV infection is lifelong and the latent virus can reactivate to cause serious illnesses when the host is immunocompromised. A potential role of CMV in colorectal carcinogenesis has also been investigated. So far, studies have provided contradictory results. Some authors were able to detect CMV DNA in colorectal adenocarcinomas by different laboratorial techniques, such as in situ hybridization and PCR [8-12]. In contrast, others failed to demonstrate the presence of CMV in tissue samples of colorectal cancer, even using the same methods of detection $[7,13-18]$. 


\section{Objectives}

Give the importance of colorectal cancer as the most common gastrointestinal cancer and detection of an infectious agent in human cancers might have important implications in cancer treatment and prevention, the present study to investigate the prevalence of CMV in patients with colorectal cancer and polyps in comparison with healthy subjects by using PCR technique conducted.

\section{Patients and Methods}

\subsection{Patients}

In this analytical case-control study, informed consent was received from all patients admitted to the endoscopy clinic of Toos and Firoozgar hospital in Tehran, Iran, between January 2013 and May 2013. Fifteen patients with colorectal cancer, 20 patients with colorectal polyps and $35 \mathrm{pa}-$ tients without malignancy as controls were studied. Sampling was performed by endoscopic biopsy operation. All collected tissues were kept frozen under $-20^{\circ} \mathrm{C}$ until analysis.

\subsection{DNA Extraction}

The DNA was extracted using the KiaSpin®Tissue Kit (Kiagen CA, Iran) according to the manufacture's instructions. In order to determine the concentration of the sample absorbance at a wavelength to $260 \mathrm{~nm}$ was performed by biophotometer system (Eppendrof, Germany). In addition, to determine the purity of the sample wavelength of 280/260 $\mathrm{nm}$ and 230/260 $\mathrm{nm}$ was also examined.

\section{3. $P C R$}

In order to determine the quality of the extracted DNA, polymerase chain reaction amplification of the gene for human $\beta$-globulin was carried out (Table 1) [19]. The mixture reaction PCR for a reaction volume of $20 \mu \mathrm{L}$ containing $10 \mu \mathrm{L}$ prime taq premix (2x), $3 \mu \mathrm{L}$ of sterile distilled water, $1 \mu \mathrm{L}$ of forward and rivers primers and $5 \mu \mathrm{L}$ of DNA template. The PCR reaction was carried out in accordance with the schedule of time and temperature. As first denaturation $95^{\circ} \mathrm{C}$ for 5 minutes, then 35 cycles of $95^{\circ} \mathrm{C}$ for 50 seconds, $55^{\circ} \mathrm{C}$ for 30 seconds, $72^{\circ} \mathrm{C}$ for 40 seconds and finally $72^{\circ} \mathrm{C}$ for 5 minutes final elongation was performed.

In order to reproduce the CMV genome of samples was performed using specific primers (Table1) [19]. The mixture reaction PCR for a reaction volume of $20 \mu \mathrm{L}$ containing 10 $\mu \mathrm{L}$ prime taq premix $(2 \mathrm{x}), 3 \mu \mathrm{L}$ of sterile distilled water, $1 \mu \mathrm{L}$ of forward and rivers primers and $5 \mu \mathrm{L}$ of DNA template. The PCR reaction was carried out in accordance with the schedule of time and temperature. As first denaturation

\begin{tabular}{|c|c|c|}
\hline Primer & Sequence $\left(5^{\prime}-3^{\prime}\right)$ & Size, bp \\
\hline \multirow[t]{3}{*}{$\mathbf{b}_{2}$} & & 106 \\
\hline & TCCAACATCAACATCTTGGT & \\
\hline & TCCСССАAATTCTAAGCAGA & \\
\hline CMV & & 167 \\
\hline$-F$ & GTCACCAAGGCCACGACGTT & \\
\hline$-\mathrm{R}$ & TCTGCCAGGACATCTTTCTC & \\
\hline
\end{tabular}

$95^{\circ} \mathrm{C}$ for 5 minutes, then 35 cycles of $95^{\circ} \mathrm{C}$ for 50 seconds, $60^{\circ} \mathrm{C}$ for 45 seconds, $72^{\circ} \mathrm{C}$ for 40 seconds and finally $72^{\circ} \mathrm{C}$ for 5 minutes final elongation was performed. Then $5 \mu \mathrm{L}$ of the PCR product on a 1.5\% agarose gel was taken.

\subsection{Statistical Analysis}

Were performed using the SPSS-20 (SPSS, Inc., Chicago, USA) software package. The relationship between the prevalence of CMV and occurrence of colorectal carcinomas and polyps and also compared with control group tissue samples were analyzed using the t-test and $\chi^{2}$ test. Statistical significance was accepted at the 5\% level.

\section{Results}

In patients with colorectal cancer, CMV DNA was found in 8 (53.3\%) of tumor samples. In patients with colorectal polyps, CMV DNA in 10 (50\%) of polyp tissues was found. CMV DNA was found in 13 (37.1\%) of patients in the control group of non-malignant. Statistical analysis showed no significant association between the prevalence of CMV and incidence colorectal cancer and polyps in comparison with the control group $(\mathrm{P}=0.226)$.

The results showed that the highest prevalence of CMV in patients with colorectal cancers older than 55 years (26.6\%), in patients with colorectal polyps in two age groups of 33 - 55 years (25\%) and over 55 years (25\%), and non-malignant control group under 35 years (14.28\%). In terms of gender, the highest prevalence of CMV in patients with colorectal cancers in men (33.3\%), in patients with colorectal polyps of women (40\%) and in non-malignant control group women $(20 \%)$ have been observed. The highest prevalence rate of the virus in patients with cancers involvement of anatomic location, proximal colon (26.7\%), patients had polyps in the proximal colon (25\%) and in nonmalignant control group were distal colon (37.1\%). Statistical analysis showed no significant association between the prevalence of CMV, age group, gender and anatomic location in patients with colorectal cancer and polyps in comparison with the control group $(\mathrm{P}>0.05)$. 
In all tissue samples 106 bp band that represents the amplification of human $\beta$-globulin gene observed (Figure 1). Due to the quality and reliability of DNA extracted, PCR analysis with CMV specific primers was performed; $167 \mathrm{bp}$ band that represent the replication is observed (Figure 2).

Figure 1. PCR Analysis of $\beta$-Globin

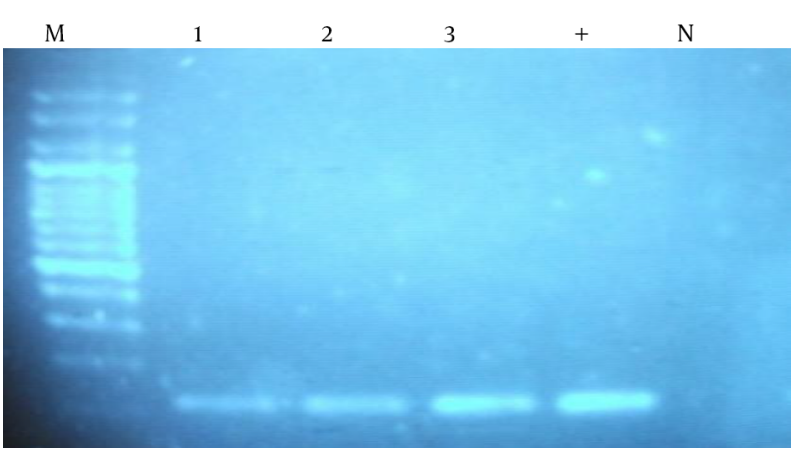

DNA extracted from tissue samples was amplified for $\beta$-globin gene using primers described in methods. Amplification yielded a band of $106 \mathrm{bp}$. As positive control (+), human DNA from fresh tissue was used; as negative control (N), PCR master mix without DNA was used; lanes 1-3, clinical samples; M, DNA molecular weight marker.

Figure 2. PCR Analysis for the Detection of Cytomegalovirus (CMV) From Tissue Samples

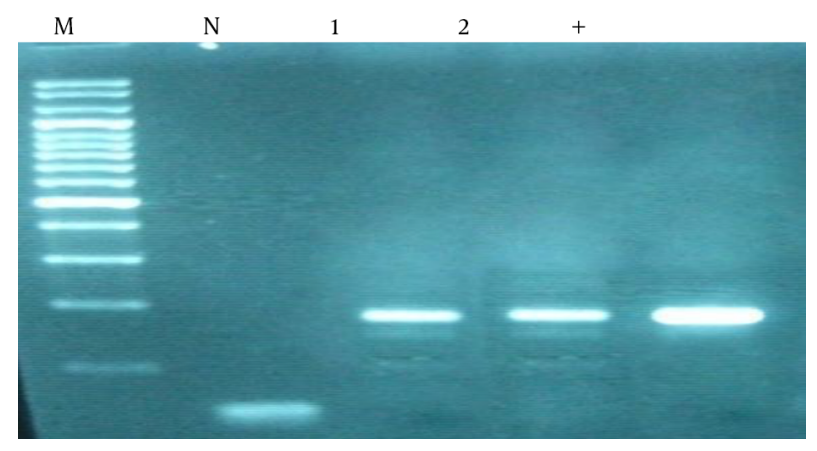

(+), Positive control; (N), negative control; lanes 1 and 2, clinical samples; M, DNA molecular weight marker. DNA extracted from tissues was amplified with specific primers. Amplification of fragment yielded a band of $167 \mathrm{bp}$.

\section{Discussion}

In this study, we investigated cancers, polyp and nonmalignant tissues for the presence of CMV DNA by PCR method. Results showed that the prevalence of viral DNA in specimens of colorectal carcinomas $53.3 \%$, in colorectal polyps $50 \%$ and $37.1 \%$ in non-malignant control group.

Since the discovery by Gross of viral causation of murine leukemia, the search for oncogenic viruses in hu- man malignancies has exploded. Based on the current understanding, it has been estimated that some $15 \%$ of the global cancer burden can be linked to oncogenic tumor viruses [20]. Various in vitro studies have demonstrated that the gene products of CMV are capable of modulating cell cycle progression and apoptosis by regulating the expression of a member of important host genes. For example, CMV infection has been shown to transcriptionally activate the expression of the proto-oncogenes c-foc, c-jun and c-myc [7]. Kalejta and Shenk [21] reported that the CMV UL82 gene product pp71 stimulates cell cycle progression by inducing protein degradation of another important tumor suppressor Rb and its family member's p107 and p130 taken together, these experimental observations strongly suggest CMV to be a potential carcinogenic agent.

The presence of HCMV antigens and genome in colorectal cancers has been obtained by means of molecular studies and a direct relationship between the virus and cancer was suggested [8-12]. The possible association of CMV with human colorectal adenocarcinomas was reported first by Huang and Roche [8] who detected CMVDNA in 4 of 7 colonic adenocarcinomas by membrane complementary RNA-DNA hybridization. It is interesting that CMV DNA also was detected in 1 of 2 cases of familial adenomatous polyposis but not in normal colonic tissues from the same patients or control cases of Crohn disease. Also, Harkins et al. [12] detected cytomegalovirus nucleic acids and proteins in a high proportion of human colorectal tumors but not in nonneoplastic colonic mucosa. However, in other studies, no evidence of a direct association between colorectal cancer and HCMV infection was found [7, 13-18]. Akintola-Ogunremi et al. [7] examined 23 colorectal hyperplastic polyps, 65 colorectal adenomas and 51 colorectal adenocarcinomas by immunohistochemical analysis with two different antibodies. No nuclear HCMV antigen positivity was detectable in any of the studied cases. In addition, PCR analysis failed to detect viral DNA in 24 selected cases showing non-specific cytoplasmic immunostaining. Knosel et al. [17] investigated the presence of HCMV DNA and antigens, by using PCR analysis. Fifty seven primary tumors and 20 metastases of fresh colorectal cancer tissue were tested, including 13 tumors pairs (primary and metastases) from the same patients. Four (7\%) of 57 primary tumors were found positive for HCMV DNA by PCR, whereas all metastases were negative. In a study by Bender et al. [18] on the presence HCMV in colorectal cancer samples, of the 56 tested tissue samples, 6 (11\%) were positive for HCMV nested PCR amplification, and more precisely 1 (5\%) of 20 cases of adenoma and 5 (21\%) of 24 cases of moderately differentiated adenocarcinoma. No PCR positivity was obtained in samples from well and poorly differentiated adenocarcinomas. These results indicating that there 
is no direct association between HCMV infection and colorectal cancer. Moreover, the results obtained are not supportive of a causal role of HCMV in the processes of carcinogenesis and progression of colorectal cancer.

The present study has shown the presence of CMV sequences in differentiated cancer tissue, polyp and nonmalignant by PCR method reflects the ability of the virus to infect of the different colon cells, but the carcinogenesis mechanism need to be clarified further.

\section{Acknowledgments}

This paper has been extracted from proposal No. 23796 (Performer: Sahar Mehrabani-Khasraghi). We wish to acknowledge the very kind help of Dr. Farzad Khalili to the sample collection. This work was supported by the endoscopy clinic of Toos and Firoozgar hospital in Tehran, Iran.

\section{Footnotes}

Authors' Contribution: All authors had equal role in design, work, statistical analysis and manuscript writing.

Funding/Support: Endoscopy clinic of Toos and Firoozgar hospital in Tehran.

\section{References}

1. Burt RW. Colon cancer screening. Gastroenterology. 2000;119(3):83753. [PubMed: 10982778].

2. Janout V, Kollarova H. Epidemiology of colorectal cancer. Biomed Pap Med Fac Univ Palacky Olomouc Czech Repub. 2001;145(1):5-10. [PubMed: 12415635].

3. Parkin DM, Bray F, Ferlay J, Pisani P. Global cancer statistics, 2002. CA Cancer J Clin. 2005;55(2):74-108. [PubMed: 15761078].

4. Allen JI. Molecular biology of colorectal cancer: A clinician's view. Perspect Colon Rectal Surg. 1995;8:181-202.

5. Lynch HT, Lynch JF. Genetics of colonic cancer. Digestion. 1998;59(5):481-92. [PubMed: 9705533].

6. Elgui de Oliveira D. DNA viruses in human cancer: an integrated overview on fundamental mechanisms of viral carcinogenesis. Cancer Lett. 2007;247(2):182-96. doi: 10.1016/j.canlet.2006.05.010. [PubMed: 16814460].

7. Akintola-Ogunremi O, Luo Q, He TC, Wang HL. Is cytomegalovirus associated with human colorectal tumorigenesis?. Am J Clin Pathol. 2005;123(2):244-9. [PubMed: 15842049].

8. Huang ES, Roche JK. Cytomegalovirus D.N.A. and adenocarcinoma of the colon: Evidence for latent viral infection. Lancet. 1978;1(8071):95760. [PubMed: 76890].

9. Hashiro GM, Horikami S, Loh PC. Cytomegalovirus isolations from cell cultures of human adenocarcinomas of the colon. Intervirology. 1979;12(2):84-8. [PubMed: 231587].

10. Grail A, Norval M. Elution of cytomegalovirus antibodies from adenocarcinoma of the colon. Gut. 1985;26(10):1053-8. [PubMed: 2996990].

11. Roche JK, Cheung KS, Boldogh I, Huang ES, Lang DJ. Cytomegalovirus: detection in human colonic and circulating mononuclear cells in association with gastrointestinal disease. Int J Cancer. 1981;27(5):659-67. [PubMed: 6270021].
12. Harkins L, Volk AL, Samanta M, Mikolaenko I, Britt WJ, Bland KI, et al. Specific localisation of human cytomegalovirus nucleic acids and proteins in human colorectal cancer. Lancet. 2002;360(9345):1557-63. doi:10.1016/S0140-6736(02)11524-8. [PubMed: 12443594].

13. Brichacek B, Hirsch I, Zavadova H, Prochazka M, Faltyn J, Vonka V. Absence of cytomegalovirus DNA from adenocarcinoma of the colon. Intervirology. 1980;14(3-4):223-7. [PubMed: 7239857].

14. Hart H, Neill WA, Norval M. Lack of association of cytomegalovirus with adenocarcinoma of the colon. Gut. 1982;23(1):21-30. [PubMed: 6276266].

15. Ruger R, Fleckenstein B. Cytomegalovirus DNA in colorectal carcinoma tissues. Klin Wochenschr. 1985;63(9):405-8. [PubMed: 2987605].

16. Boguszakova L, Hirsch I, Brichacek B, Faltyn J, Fric P, Dvorakova H, et al. Absence of cytomegalovirus, Epstein-Barr virus, and papillomavirus DNA from adenoma and adenocarcinoma of the colon. Acta Virol. 1988;32(4):303-8. [PubMed: 2903634].

17. Knosel T, Schewe C, Dietel M, Petersen I. Cytomegalovirus is not associated with progression and metastasis of colorectal cancer. Cancer Lett. 2004;211(2):243-7. doi: 10.1016/j.canlet.2004.02.011. [PubMed: 15219948].

18. Bender C, Zipeto D, Bidoia C, Costantini S, Zamo A, Menestrina F, et al Analysis of colorectal cancers for human cytomegalovirus presence. Infect Agent Cancer. 2009;4:6. doi: 10.1186/1750-9378-4-6. [PubMed: 19371403].

19. Zaravinos A, Bizakis J, Spandidos DA. Prevalence of human papilloma virus and human herpes virus types 1-7 in human nasal polyposis. J Med Virol. 2009;81(9):1613-9. doi: 10.1002/jmv.21534. [PubMed: 19626617].

20. zur Hausen H. Oncogenic DNA viruses. Oncogene. 2001;20(54):7820-3. doi:10.1038/sj.onc.1204958. [PubMed: 11753664].

21. Kalejta RF, Shenk T. Proteasome-dependent, ubiquitin-independent degradation of the $\mathrm{Rb}$ family of tumor suppressors by the human cytomegalovirus pp71 protein.Proc Natl Acad Sci USA. 2003;100(6):32638. doi:10.1073/pnas.0538058100. [PubMed:12626766]. 